\title{
YESTERDAY, TODAY AND TOMORROW: IS SOCIAL WORK SUPERVISION IN SOUTH AFRICA KEEPING UP?
}

\section{Lambert Engelbrecht}

\section{INTRODUCTION}

The recruitment and retention strategy of the Department of Social Development (2006:23) postulates that there is a "lack of structured supervision and poor quality supervisors, who themselves also lack capacity to conduct professional supervision" in South Africa. Pieterse (1961), one of the first authors on supervision in South Africa, made similar claims close to five decades ago. These two comments give rise to the question: has social work in South Africa been practising supervision over the past five decades beyond historical bureaucratic discourses, and has it engaged with changing global, local and personal contexts to develop and sustain critically responsive practices? In other words: is social work supervision in South Africa keeping up with the times? By addressing this question, this paper seeks to respond to the call of the recruitment and retention strategy document (Department of Social Development, 2006) to evaluate current supervision practices. In this attempt the paper reports on research, drawing on an historical analysis of the international and local development of social work supervision and on a case study of current supervision practices in an NGO environment, in order to recommend a context-specific conceptual framework for future supervision practices. This paper thus aims to examine the interplay between the historical development, current practices and future challenges of social work supervision.

\section{THE INTERNATIONAL AND LOCAL DEVELOPMENT OF SOCIAL WORK SUPERVISION}

Supervision is not a new concept. It has been practised in social work, psychotherapy, counselling and clinical psychology for decades. However, the immediate roots of what we have come to know as supervision in the human service professions lie in the historical development of social work per se (Lave \& Wenger, 1991).

\section{International context}

The origin of social work supervision internationally is embedded in its administrative function (Shulman, 1995; Tsui, 1997) and can be traced back to the Charity Organisation Societies (COS) movement in Europe and North America, which began in 1878 (Munson, 2002). This administrative function involved the recruitment, organisation and overseeing of volunteers and later paid workers (Pettes, 1967). As casework practices became more sophisticated through the work of pioneers such as Mary Richmond (1899) and demands for paid workers grew, a body of literature on supervision as subject in social work evolved following Brackett's (1904) book, Supervision and Education in Charity. As a result of this publication, supervision acquired an educational purpose in 1911, when the first course in supervision was offered by Mary Richmond in the USA (Burns, 1958). Also, the hierarchical position of the supervisor was revealed as the paid agent supervisor was in a middle-management position, as are supervisors today, supervising workers under the authority of agency administrators. This middlemanagement position of supervisors tends to feature in all the literature on social work supervision (Kadushin, 1992:6).

The administrative function of supervision was dominant throughout the 1800s (Tsui, 1997). However, the publication of Virginia Robinson's (1936) book, Supervision in Social Case Work defined supervision also as an educational process and led the way for other significant 
publications on the educational function of supervision of social workers. At the same time, from the 1930s until the 1950s, psychoanalytic theory emerged as a major theory in social work and had a pertinent impact on the format and structure of future social work supervision (Austin, 1981). The 1950s to the 1970s were particularly characterised globally by debates about the value of, and the need for, continuing social work supervision of professionally trained social workers, as independent practice was regarded as a hallmark of a well-developed profession. Some social workers, however, perceived long-lasting supervision as an insult to their professional status (Tsui, 1997). This debate about interminable supervision and autonomous practice is still lively and relevant today.

Tsui (1997) categorised the international development of supervision into four critical stages, namely: stage 1 - administrative roots (1878-1910); stage 2 - a change of context of supervisory training and emergence of a literature base (1911-1945); stage 3 - influence of practice theory and methods (1930s-1950s); and stage 4 - debate about interminable supervision and autonomous practice (1956-1970s). In South Africa supervisory practices developed along similar lines until the 1960s (Hoffmann, 1987).

\section{South African context}

Against the background of Tsui's (1997) four stages of historical development, the historical development of supervision locally can be placed broadly into three periods.

\section{Emerging and predominantly administrative years (1960-1975)}

One of the first articles published on supervision in South Africa focused on supervision in a group work context (Pieterse, 1961) and referred to supervision as field guidance. In 1962 this field guidance figured prominently as a form of in-service training in the Department of Social Welfare and Pensions (De Jager, 1962). Additionally, in 1965 Du Plessis emphasised the inclusion of both the administrative and educational function of supervision in a fully-fledged supervision system operating in the Department of Social Welfare and Pensions and agitated for the training of supervisors at South African universities. Notably, her evaluation was that the working conditions of social workers hamper their focus on their professional work and that supervision was consequently not receiving the rightful and dedicated attention it deserved, thus preventing social work professionals from taking their service rendering to higher levels (Du Plessis, 1965:115, 116). Of special interest is Botha's (2002:1) similar conclusion, albeit 37 years later. Another point of interest within the context of the politically turbulent times in South Africa of the late 1960s was the specific exploration of student supervision in Black colleges by Bopape (1968), indicating that practices relating to all the peoples of South Africa contributed to the local development of social work supervision.

The interest in supervision locally was also complemented by a range of scholarly articles on supervision as a learning experience in Social Work/Maatskaplike Werk, a professional journal for the social worker, by Barette (1968a, 1968b). In the same year a national conference on field guidance also contributed to the contextualising of supervision in the South African context (Hatting, 1968). Field guidance was defined as "that part of supervision whereby social workers are familiarised with the policy, administrative and organisational aspects of the institution where they are employed" (Terminology Committee of Social Work, 1995:25). Clearly supervision during this era was mainly rooted in a need for administrative practices along hierarchical lines, but with an emerging perception of education as an additional function of supervision. This is demonstrated by Botha's (1971) exposition of administration, education and consultation as functions of supervision, with reference to the problem-solving process of 
Perlman (1967). Subsequently, the beginning of the 1970s marked a turning point in the development of supervision in South Africa, as the defining dictionary of social work, published in 1971, provided an official definition of supervision. This definition was, however, only in Afrikaans, did not refer specifically to any supervision functions and defined supervision as a process through which a supervisor could help social workers to accomplish their professional tasks as efficiently as possible (Vaktaalkomitee vir Maatskaplike Werk, 1971). Based on this conceptualisation, various South African literature contributions by scholars such as Botha (1972), Smit (1972), Dercksen (1972) and Hoffmann (1976) followed, and drew mainly on supervision texts published by scholars in North America.

\section{Period of integrated supervision functions and escalation of knowledge base (1975-1990)}

The most prominent North American scholars of the late 1970s and early 1980s were researchers such as Kadushin (1976), who was the first to observe that providing support to social workers was a significant function of supervision; Austin (1981), who identified the managerial demands experienced by supervisors; and Middleman and Rhodes (1985), who placed supervision within a social and political context. The work of these scholars was reflected in South African supervision texts, where Botha (1985a) and Pelser (1985) agitated, at a symposium on supervision held at the University of Pretoria, for efficient supervision content and skills in social work, and the scientific and professional justification of supervision respectively. In addition, Botha's (1985b) seminal work on the education model for efficient supervision laid the foundation for the practice and training of supervisors in South Africa, as during that time a localised study of De Bruyn (1985) revealed a lack of supervision training. In 1985 postgraduate supervision courses were offered at only two out of 20 universities - the first course was instituted as late as 1978, some 74 years after the first social welfare organisation was formed in the country and 52 years after the first formal social work programme was offered at a university (Hoffmann, 1987). Hoffmann (1987:222) furthermore contended that, "Although supervision in one form or another has featured in the administrative practices of human service organizations in South Africa since their inception, the quality and dimensions of its practice tend to fall short of theory outlined thus far." In response, several South African universities instituted formal theoretical courses in supervision at Honours and Masters levels, with some universities even expecting candidates to complete a supervised field instruction component of study. Finally, social work supervision became reputable in South Africa, as demonstrated by Pelser's (1988) work on practice guidelines for supervision.

\section{Times of change (1990s and beyond)}

A plethora of academic theses, especially Masters dissertations followed for more than a decade until near the end of the previous millennium, when supervision as a research topic became less favoured, as a result of the rise of other more burning social development issues and interrelated changes in postgraduate programmes. Also, with the transition to, and embrace of, a new political dispensation and welfare system in South Africa, the focus of research was more on priorities of service delivery than on human resources issues (Engelbrecht, 2006a). A massive migration of South African social workers to other countries and employment outside the social work domain followed, especially after 1997, and has been continuing for at least a decade, resulting in a lost generation of social workers. This lost generation represents almost the same number of seasoned social workers (who were in most cases in supervisory positions) as newly qualified social workers (Engelbrecht, 2006a) and this consequently has an impact on the deterioration of supervision knowledge and skills as a whole. The government's recognition 
of social work as a scarce skill in 2006 (Department of Social Development, 2006) may also be regarded as a confirmation of the "brain drain" (Engelbrecht, 2006a) of supervision expertise.

Moreover, because of the nature of academic programmes at universities, many dissertations on supervision over the past decades were modest in scope, were idiosyncratic to specific contexts and findings, and although indisputably scholarly, could in many instances not be generalised beyond samples. An extended examination of these studies reveals that most dissertations were initially expositions of demarcated supervision-related research themes, based primarily on North American texts by authors such as Kadushin (1976), Austin (1981), Middleman and Rhodes (1985), Bunker and Wijnberg (1988), Shulman (1993) and Munson (1993). Gradually, local dissertations started to draw increasingly on other postgraduate candidates' texts, and ultimately presented these secondary texts as their main frame of reference, resulting in rather misplaced contexts and practices. Botha (2002) redressed this matter in the most comprehensive text on supervision in South Africa, which is an updated version of her supervision literature contributions since 1971. She pleaded for the launch of comprehensive research programmes on the nature of supervision in South Africa, since research on the impact of supervision on all levels of social work had been sorely neglected whereas the international supervision environment had changed extensively, mainly because of an increase in research on the subject. She argued that, "There are too many instances where outdated and obsolete customs are still adhered to and where no attempts are made to renew supervision practice" (Botha, 2002:3).

The evolution of the situation as addressed by Botha (2002:3) was anticipated by Hoffmann (1987:222-226) 15 years earlier, when she presented recommendations regarding the future of supervision practices in South Africa. These recommendations involved variables contributing to the state of supervision practices of that time, such as the education of social workers for supervision, education of top management on supervision, working conditions of social workers and supervisors, the migration and emigration of social work professionals, new welfare policies, diversity issues and theoretical developments. At face value these identified variables not only contributed to supervision practices of the past decade, but still have an indisputable impact on the current status of social work supervision in South Africa. This supposition thus warrants empirical investigation: to examine current practice traditions leading to recommendations to be taken into account in future - not only on supervision practices that ought to be in place, but also on those that could be in keeping with the times.

\section{THE CURRENT STATUS OF SUPERVISION IN SOUTH AFRICA}

To investigate the status of supervision in South Africa an instrumental case study as described by Fouché (2005:272) was employed, because it would facilitate an in-depth understanding of the current practices as the social issue concerned.

\section{Research methodology}

The current practices of social work supervision were investigated by means of a crosssectional exploratory and descriptive research design on the basis of Grinnell, Unrau and Williams (2005:16-18) and McMurty (2005:274). The empirical investigation thus fell within the parameters of a qualitative research methodology. A traditional child and family-oriented social welfare NGO, based in three provinces in South Africa, was chosen as the field of research. The organisation is governed by the Non-Profit Organisations Act (Ministry of Welfare and Population Development, 1997) and the government policy on financial awards to service providers (Department of Social Development, 2005). This ensures that the NGO meets 
certain operational requirements before being eligible for a financial award from the National Department of Social Development. The NGO renders its services guided by a business plan that has to be submitted to the government for funding. This business plan has to support the mission of the Department of Social Development (Department of Social Development, 2003). Thus, although the identity of the NGO is secured, operational and consequentially management and arising supervision practices in the NGO concerned could well be regarded as a broad reflection of practices in South Africa.

Non-probability sampling as described by Schutt $(2005: 164)$ was utilised, because the idea, following Stake (1995), was merely to obtain in-depth data for the opportunity to learn from participants' experiences and perceptions. Consequently a purposive sample for a key informant survey (Schutt, 2005:166) targeted 7 supervisors and 14 front-line social workers (2 social workers supervised by each supervisor) employed by the NGO concerned. The characteristics of these key informants correspond broadly with Earl's (2008) findings on the profile of social workers in South Africa, in that the participants were female, from different population groups and mostly between the ages of 25 and 44. The supervisors and social workers were located equally in urban, semi-urban and rural areas. The work experience of the supervisors on middle-management level ranges from 1 to 35 years and that of the social workers as front-line workers ranges from 6 months to 28 years. All the participants are professionally qualified social workers registered with the South African Council for Social Services Professions. The social workers all render integrated social services through case work, group work and community work from a social development perspective within the parameters set by the White Paper for Social Welfare (RSA, 1997) and as proposed by the Department of Social Development's Integrated Service Delivery Model towards improved social services (RSA, 2006b). The work-related experiences and perceptions of the supervisors and social workers could thus be broadly extended to include supervisors and social workers in other South African contexts.

In-depth, semi-structured, one-to-one interviews were utilised as a data-collection method as expounded by Gochros (2005:250-251), by using an interview schedule, based on the variables for supervision practices as identified by Hoffmann (1985) and Botha's (2002) exposition of supervision and consultation in social work, as well as primary texts on supervision such as those by Kadushin (1976), Austin (1981), Middleman and Rhodes (1985), Bunker and Wijnberg (1988), Shulman (1993) and Munson (1993). These texts were supplemented by articles from relevant journals, especially The Clinical Supervisor. The theoretical frame of reference and empirical data of the case study were triangulated as suggested by Leedy and Ormrod (2001:149) in order to make recommendations for the future of supervision practices in South Africa. A significant aspect of the research methodology is that a process consisting of a movement between inductive and deductive logic and reasoning (Siepert, McMurty \& McClelland, 2005:323) was used to examine the case study within international and local contexts.

To ensure validity (Marshall \& Rossman, 1999) of findings, certain parameters were adhered to in the research process: the above-mentioned exposition on the development of social work supervision serves as a theoretical frame of reference and contextualisation; the broad history of the NGO and the biographies of the supervisors and social workers in the case study delineate the setting and population of the research; the experiences and perceptions of supervisors and social workers serve as specific answers to the research question; the elucidation of the case study serves as an integrated triangulation of multiple sources of data; 
and the distinct challenges constructed and held out to supervisors and management structures serve to indicate the anticipated future for supervision practices in South Africa, providing the ultimate outcome of the research.

\section{Case study}

The discussion below deals with the findings of the case study.

\section{Working conditions of social workers and supervisors}

The overarching issue arising from discussions alluding to any component of their work is a great uneasiness by the case study participants' about their working conditions. Participant social workers' reflections such as "never mind supervision and everything else...I have to keep the work going" despite meagre resources and personal incentives, and a supervisor saying that "supervision is the last thing on my mind", give substance to the fact that supervision practices are overshadowed by other structural work-related issues. Supervisors are statutorily coresponsible for the actions of their supervisees, according to the Social Service Professions Act (RSA, 1978), but the supervisors' responses clearly demonstrate that supervision of social workers is just one part of their work responsibilities. Social workers, on the other hand, rightfully regard their supervisors as part of the organisation's management hierarchy, which is held responsible for not successfully bargaining fair working conditions. To this end, it is noteworthy that this scenario reflected by the participants of the case study has remained unchanged since one of the first published confirmations of fully-fledged supervision practices in South Africa reported a similar situation more than four decades ago (Du Plessis, 1965:115, 116), and was reiterated by Botha (2002) after the advent of the millennium.

Poor working conditions and their negative impact on supervision are ascribed to funding shortages (Hoffmann, 1987). The reality of funding shortages, however, points to organisations' need to institute cost savings, predominantly in terms of social workers' remuneration. In addition, cost savings also translate typically negatively into the supervisorsupervisee ratio, which is a worldwide phenomenon (Gibelman, 1995). Hence, poor working conditions have to be taken into consideration in any discussion on supervision practices in South Africa, and they also have an impact on the training of supervisors, determined as a contentious issue since the establishment of a national Department of Public Welfare in 1937 (Müller, 1965).

\section{Training of supervisors}

Except for an internal organisational orientation on supervisory responsibilities, no participant supervisor in the case study is in possession of a formal qualification in supervision or has ever attended an accredited supervision course. The scope of the participants' supervisory responsibilities captured mainly middle-management tasks, with professional supervision of social workers, as already indicated, as just one of their assignments. This scope of responsibilities mirrors a local debate around management as a function of supervision as expounded by Kadushin (1976) and advocated by Botha (2002), against supervision as an integrated part of the middle-managers' human resources function (Booley, 1996). Nevertheless, despite the differences in scope and perspective, the fact remains that academic or at least formalised state-of-the-art training in supervision is not a requirement and not common for supervisors in middle-management positions. This fact can also be linked to the above-mentioned lost generation of seasoned social workers and consequential loss of academically obtained supervision capacity. However, since 2007, in a positive move towards supervision training, all undergraduate social work curricula at universities must comply with 
the South African Qualification Authority's (SAQA) requirements to meet specific outcomes (Earl, 2008). One category and outcome of the BSW qualification specifies that learners must demonstrate an understanding of the roles, functions, knowledge and skills for effective social work supervision and consultation (Lombard, Grobbelaar \& Pruis, 2003). A practice scenario could thus reveal a beginner social worker with more theoretical knowledge on supervision than her supervisor. Another concern is that it is unclear whether organisations and supervisors at present are familiar with the specific content on supervision that equips newly qualified social workers to act as supervisors for volunteers and auxiliary workers. Ideally, organisations and supervisors should lock onto these academic developments. Furthermore, the government's retention and recruitment strategy (Department of Social Development, 2006) emphasises that the dearth of supervisors in practice is exacerbated by the perception that trained supervisors are not necessary. This perception is intrinsically connected to various notions on the significance of supervision (Kadushin, 1992; Munson, 1993).

\section{The significance of supervision}

Despite all the case study participants' preoccupation with generally poor working conditions colouring their disposition towards supervision, and although differences were observed in perceptions of seasoned social workers, newly qualified workers and supervisors, they all asserted the absolute necessity of effective supervision practices. A typical response of seasoned workers was: "I need a soundboard and some authority, especially with the implementation of the new Children's Act." Newly qualified workers typically replied: "I need direct guidance all over to do the job, especially solid support." A supervisor said: "Since I'm co-responsible for what the workers are doing, I have to protect myself, the worker and clients." These responses concur with Kadushin's (1992) claim that although there are commentators who feel supervision is unnecessary and should be replaced by autonomous practice, the format and structure of social work supervision (and even the term supervision) have remained constant worldwide over the past 80 years. Kadushin (1992) is renowned for his inventory of reasons for maintaining interminable supervision: political accountability and administrative control, and the educational function and supportive function of supervision. Moreover, there is currently a growing regard for supervision as one of the main factors in the retention of social workers (Juby \& Scannapieco, 2007), which complements the reference to supervision in the government's retention strategy (Department of Social Development, 2006). Most importantly, cutting-edge international research confirms that supervision contributes to competent professional practice that serves the best interests of clients - findings which translate into the goal of supervision (Gilbert, 2009).

\section{Goal of supervision}

Participants reflect their understanding of the goal of supervision as the development of social workers into competent, independent and autonomous practitioners, as stated in their organisation's manual. However, recent goal formulations of supervision (Nye, 2007) provide supervisees with an alternative model of development in supervision, one that acknowledges the need for on-going dependence on continuous learning and development across their professional career. Such dependence is regarded as necessary and inevitable, if learning and development are to occur. The focus on worker's independence can, however, be regarded as a secondary goal of supervision, since an array of contemporary texts on supervision define the goal of supervision as to deliver to service users the best possible service, both quantitatively and qualitatively, in accordance with the organisation's policies and procedures (Coleman, 
2003; Kadushin \& Harkness, 2002; Tsui, 2005). Indeed, this goal of supervision is intrinsically linked to the definition of supervision.

\section{Definition of supervision}

Supervision has been defined in various ways at different times (Barker, 1995). Both supervisor and social work case study participants define supervision in terms of "control", "guidance" and "support", which according to Tsui (2005) suggests a normative approach to the definition of supervision, as it answers the question on what should the supervisor does. This definition concurs with the $19^{\text {th }}$ edition of the Encyclopaedia of Social Work (Shulman, 1995) and the South African New Dictionary of Social Work's comprehensive definitions of supervision (Terminology Committee, 1995), which include supervision's administrative, educational and supportive functions. Tsui (2005) also argues for a pragmatic approach to supervision which does not focus on providing a formal definition of social work. Instead, its aim is to provide action guidelines for social work supervisors. An example of this approach is to be seen in the government's recent retention strategy (Department of Social Development, 2006), where supervision is referred to in the sense of a management function, as a means for evaluation, an enhancement of workers' professional functions, as transferring of skills, as mentoring, professional support and monitoring of quality services. Tsui (2005) furthermore suggests an empirical approach to the definition of supervision, which entails the collecting of empirical data about the roles, styles and behaviour of supervisors.

However, determining distinctions between the roles of supervision within clinical and administrative or traditional contexts has been contentious as there are no uniform definitions for these contexts of supervision (Bernard \& Goodyear, 1992). It is thus imperative to note in this regard that mostly all the international texts from which local scholars draw are from a clinical context (Kadushin \& Harkness, 2002; Munson, 2002; Shulman, 1993). The main distinction between clinical supervision and traditional social work supervision is that the former does not necessarily concern practice within an organisational context and focuses mainly on the dynamics of a client's situation and the social worker's interventions (Bogo \& McKnight, 2005; Lewis, Packard \& Lewis, 2007; Tromski-Klingshirn, 2006). Clinical supervision is also practised by a range of interdisciplinary professionals or para-professionals such as psychologists, nurses, marriage and family therapists, psychiatrists, substance abuse counsellors, education counsellors, speech therapists and social workers (Fifth International Interdisciplinary Conference on Clinical Supervision, 2009). Conversely, in South Africa traditional supervision as defined by scholars such as Botha (2002) is practised only by social workers and other social service professions, such as social auxiliary workers, probation officers, community development workers, and child and youth care workers (SACSSP, 2008). The definition of supervision is thus interdependent on either interdisciplinary clinical or traditional social work contexts - an aspect that has not always been taken into account in South African texts and practices. Furthermore, the social development paradigm of South African social welfare practices (RSA, 2006b) may be regarded as antipodal for clinical practices. Although supervision within a social development perspective has been described in a South African text (Engelbrecht 2002), this particular text focused on student supervision, which has its own dynamics and cannot be translated to supervision of social workers.

\section{Functions of supervision}

The above-mentioned definition of supervision points to the link between the definition and the functions of supervision. Kadushin's (1976) postulation of the functions of supervision draws on definitions by earlier commentators such as Dawson (1926). Scholars such as Hardcastle 
(1991) and Middleman and Rhodes (1985) identified alternative terms for supervision functions, which in fact describe either subsidiary functions or extensions of administration, education and support. However, the operationalising of supervision functions is context specific (Doel \& Shardlow, 1996; Erera \& Lazar, 1994; Tsui, 2005). This is illustrated by the case study participant social workers' comments, which generally reflect dissatisfaction with the operationalising of supervision functions and range from "supervision in my situation has only one function - to exercise control over my work", to "I'm in desperate need for support in my work. I have to deal with severe traumatic situations, but my contact with my supervisor is minimal and mainly based on inspection of my work." A newly qualified supervisee said: "I don't know what I'm supposed to know", as opposed to a seasoned supervisee who commented: "My supervisor can tell me nothing I don't know - but she has the red pen for signing off my reports." In addition, supervisor participants' comments can be summed up by the following two comments: "I know that I don't give enough attention to my workers, especially in terms of support and training. It's awful and I am constantly feeling guilty, but I really don't have the time to nurse them and am just surviving myself", and "I also need support, but got nobody to turn to - I'm on the edge of a breakdown."

From the case study participants' comments it is evident that the operationalising of supervision functions should be blended to be normative (ensuring that the supervisee's work is professional in accordance with organisational and statutory norms), formative (developing the supervisee to become increasingly competent) and restorative (enabling the worker to mobilise emotional energy needed for effective job performance) (Bluckert, 2008). However, the way in which these functions are depicted tends to consider supervisees (and supervisors) to be in deficit. Recent inter-country research between South Africa, England and Sweden (Bradley, Engelbrecht \& Höjer, 2010) raises the issue of supervisor stress and suggests the creation of a safe culture and environment in which supervisors can deal with uncertainty and stressors, and where they can discuss their weaknesses and failings, as an important element of supervision. In the same vein, contemporary commentators such as Coleman (2003) argue against a deficit orientation in the operationalising of supervision functions and agitate for an orientation that emphasises a concern for fostering an environment in which workers can take responsibility for their own actions and where supervisors do not slip into acting on behalf of supervisees. This orientation towards the creation of facilitative environments is embedded in the nature of the practice theories and models utilised in supervision.

\section{Practice theories and models of supervision}

Suggestions by Cohen (1999) regarding a strengths-based perspective on supervision relate to the creation of facilitative environments as proposed by Coleman (2003) and discussed in the previous section. New theoretical developments also concur with a strengths-based perspective on supervision, in that this perspective is an integral part of a competence model of supervision, which is proposed to empower social workers (Engelbrecht, 2004). The competence model of supervision (Page \& Stritzke, 2006) furthermore correlates with outcomes-based supervision, and is thus in line with SAQA's requirements to meet specific learning outcomes in academic training (Lombard et al., 2003). A strengths perspective, competencies and empowerment are all concepts peculiar to a social development approach to social welfare (RSA, 2006b) and could therefore be essential in constructing an appropriate theoretical conceptual framework for supervision in South Africa.

An exploration of the case study participants' employment of specific practice theories and models of supervision revealed that the participant social workers were not aware of the 
existence of any practice theory or model of supervision at all. Participant supervisors, however, referred to their organisation manual, which states that supervision is based on a situational leadership model in the organisation. These participants could only recall the name of the model, but had no knowledge of the model's theoretical underpinning. For example, one supervisor said: "I just complete the forms of the supervision manual and that's it". Indeed, Hersey and Blanchard's situational leadership model (Hersey, Blanchard \& Johnson, 1996) can be helpful to supervisors in a context in which supervisees may vary greatly in terms of their readiness levels. However, according to this model, the goal of supervision is stated as the enablement of the social worker to function independently - a notion which was discussed in the previous section on the goal of supervision and which may be regarded as contentious and debatable. Moreover, it would be naïve to argue that a single model or particular orientation fits all aspects such as environments, level of supervisor and supervisee experience, values, personal characteristics and so on (Kaufman \& Schwartz, 2003).

Theories on supervision have historically been derived from applying models of therapy and from extrapolating models from other fields. Nevertheless, Botha (2002) rightfully remarks that many models were developed over years, rewritten, new names were ascribed to them and several were merged - all to accommodate a myriad influences over time. Even the focus of different commentators' practice theories and models is confusing. Botha (2002) for instance refers to models of and approaches to education (with a definite distinction between models and approaches). Kaufman and Schwartz (2003), on the other hand, refer to models and approaches in the same sense, but within the context of all the supervision functions. To clarify the differences in interpretations, typified by Tsui and Ho (1998:182) as a "supervisory jungle", Tsui (2005:20) offered five categories of supervision models in social work. One of Tsui's defined categories tends to focus merely on political issues (the feminist partnership model). The other four categories of supervision models are more applicable to the South African context and may be translated as practice theory models, which are based on the theories, models and perspectives social workers employ in their interventions; structural-functional models, which refer to supervision functions; organisation models, which reflect the practice of supervision within a specific organisational structure and by means of distinctive supervision methods; and interactional process models, which focus on the interaction between the supervisor and the supervisee in the supervisory process. These categories of supervision models (practice theory models, structural-functional models, organisation models and interaction process models) serve as "a simplified picture that acts as an aid to understanding reality" (Tsui, 2005:17) and culminate in the content of supervision.

\section{Content of supervision}

The actual content of supervision is driven by the supervision functions, which have been discussed already in this paper. Botha's signature supervision process, which she defines as "the foundation of supervision" (Botha, 2002:100), is based on an educational process where "attention is given to the learning needs that exist on the administrative, educational and/or supportive levels". Her composition of an educational model, based on Perlman's (1967) problem-solving process and Kadushin's (1976) exposition of it, is a definitive, comprehensive, unique framework for holistic supervision practice. However, the philosophical and theoretical underpinning of this frame of reference and the compatibility with contemporary theoretical developments in social work, such as a strengths-based perspective (Cohen, 1999), competence model of supervision (Page \& Stritzke, 2006) and an outcomes-based orientation (Lombard et al., 2003) are ambiguous. Be that as it may, Botha's (2002) particular notions of principles of 
adult education, educational techniques, styles and patterns as well as her expositions of an educational evaluation, programme and contract definitely withstand the theoretical developments of the times, as contemporary commentators such as Coleman (2003), Hawkins and Shohet (2006), Tsui (2005) and Lewis et al. (2007) present the same notions, although their views are substantiated with altered, present-day terminology. Nevertheless, supervisor as well as supervisee participants of the case study could not reflect on their application and utilisation of the supervision content as discussed here. Hence, the participants follow no identifiable supervision process and are not aware of principles, techniques and styles to be employed.

\section{Supervision methods}

Case study participants reported that the one-on-one supervisee and supervisor dyad is the default supervision method in operation, which agrees with international research by Bogo and McKnight (2005) and Hensley (2002) on this topic. Group supervision takes the form of staff development, according to the participants. No other method of supervision, such as peer supervision as described by Bogo and McKnight (2005) and Tsui (2005) is exercised by participants. Although coaching and mentoring (Bluckert, 2008; Collins-Camargo \& Kelly, 2006; Connor \& Pokora, 2007; Lewis et al., 2007; Perrault \& Coleman, 2005) are described in recent texts as emerging supervision methods, participants responded that these methods are not formalised and in use.

\section{Consultation}

Coleman (2003) states that consultation is sometimes confused with supervision and concludes that there is a definite distinction between the two modes. Although consultation may involve some of the same functions of a supervisor, it does not usually carry administrative responsibilities and accountability. Case study participants could shed no light on the differences between supervision and consultation. One social worker participant reflects: ' $I$ ' $m$ on a so-called consultation level, but the only difference with supervision is that I now see my supervisor less. She still has to sign my statutory reports and still inspects my work." In this context it seems that the participant's supervisor is also regarded as her consultant. This is in direct opposition to international position statements, such as that of the American Board of Examiners in Clinical Social Work (2004). This particular Board drew the distinction between an agency-employed supervisor in an organisation, who confers authority and accountability, and a consultant who is not given authority as a supervisor and who rather provides education, support and expert opinions. As an additional distinction from the Anglo-American tradition of supervision in social work, the supervisor in Scandinavian and other European contexts, for example, comes from outside the organisation in which the supervisee is employed - which is normally referred to as external supervision. The supervisor's position is rather comparable to that of a consultant, bearing responsibility only for the educational supervision process and support (Bradley et al., 2010). Creative contemporary modes of consultation thus exist, which specifically have an impact on the context-specific organisation model and structural-functional model employed in an organisation.

\section{ANTICIPATING THE FUTURE OF SOCIAL WORK SUPERVISORY PRACTICE}

The findings of the above case study clearly reveal that social work supervision practices in South Africa have not kept up with international theoretical and local social developments since the changing times of the 1990s. As a consequence, Hoffman's (1987:222-226) recommendations for future supervision and Botha's (2002:3) conclusions, which serve as premises for the empirical study reflected in this paper, are still relevant. Although the 
significance of supervision is emphasised by the case study participants, the goal and definition of supervision in leading South African texts (Botha, 2002) are diffused and clinically orientated, based as they are on action guidelines (Department of Social Development, 2006), but not specifically framed within a social development paradigm. It is furthermore evident from the case study that formalised academic training of supervisors is still lacking and that the functions of supervision remain centred on a deficit orientation with administrative control as the basic premise. The figuration of context-specific and structural-functional, organisational and interactive process models is also not common. Moreover, consultation appears to be diffused against the use of internationally creative contemporary models. Based on these findings, the future of social work supervisory practice within a social development paradigm is anticipated and addressed to supervisors, but specifically to management structures on the micro and national levels.

- The emergence of a postmodernist orientation in supervision is occurring through social constructionist practice approaches such as solution-focused and strengths-based practices. Social constructionist approaches recognise that supervision in any particular context is shaped and influenced by global, local and personal determinants (O'Donoghue, 2002). A renewed future interest in supervisee empowerment and more explicit recognition of the different contexts and discourses in which social work supervision is immersed should be cultivated by all parties involved in social work in South Africa. A prerequisite for a social constructionist approach to supervision should, however, be fair working conditions for social workers and supervisors.

- Within the context of globalisation and neoliberal social work's emerging emphasis on managerialism and marketisation (Ferguson, 2009), the operationalising of the following specific recommendations on the fundamentals of supervision is proposed:

- Standardised, accredited and accessible supervision training should be developed by partnerships between organisations and universities to complement the social development theoretical paradigm practised in South Africa and the specific outcomes on supervision of the BSW qualification. To be nationally registered as an accredited supervisor should also be a future option.

- The definition of supervision should institute a movement away from a deficit and merely clinical orientation, and should be a national endeavour in order to contextualise supervision in South Africa in line with the Integrated Service Delivery Model of the Department of Social Development (RSA, 2006b).

- The functions of supervision should be optimised by supervisors to deliberately embrace other functions rather than just fixating on the administrative function, without negating control as a management function, which will be more prominent in future with the inception of the new Children's Act, No. 38 of 2005 (RSA, 2006a).

- Practice theories of supervision, focusing on specific outcomes-based and competency interaction models, should be developed by individual organisations and supervisors by means of research to include samples from the organisation's multiple sites, representing a range of geographical locations and service sections.

- The content of supervision practices should be revisited and reconceptualised by supervisors and individual organisations with the aim to fit their specific contexts in a facilitative, practical, user-friendly and caring way without inhibiting the development of social workers' professional identity and continuous learning. Ultimately, all 
organisations employing social workers should have a comprehensive policy directing the content of supervision, which ideally could also be operationalised as the key to the recruitment and retention of staff.

- Supervision methods should be expanded by organisations' supervision policies beyond individual supervision on a face-to-face basis. Internet-based supervision as an alternative in rural areas and peer supervision, mentoring and coaching as specific empowerment activities in the protégé's career development should also be employed.

- The contextualisation and practice of consultation should be a national endeavour to obtain government-extended funding opportunities, especially in the context of external supervision/consultation practices for the benefit of education and support of social workers.

- The historical analysis of supervision practices reveals that values in the traditional view of supervision reflect dominant notions of Western individualism and paternalism, and promote a form of homogeneity based on a heterosexual imperialist male worldview (O'Donoghue, 2002). Culturally friendly values (Engelbrecht, 2006b) that do recognise the needs of all people of diverse backgrounds, gender and worldviews should be constructed in a context-specific way by individual organisations in order to be operationalised by supervisors as the foundation of South African supervision practices.

- The same ethical violations that can occur in a social work-service user relationship can be paralleled in a supervisory relationship (Dewane, 2007). Although professional conduct is included in the ethical code of the SACSSP (2007), neoliberal productivity standards in a managed and care environment increasingly create ethical compromises for social workers and supervisors when marketing and profit become the principal drivers. Therefore a visionary national ethics audit within the context of supervision could add value to the professional conduct of supervisors and social workers, and should result in minimum standards as benchmarks for supervision in South Africa.

\section{CONCLUSION}

An overview of the historical development of supervision shows that the quality of social work service delivery has always been determined by the quality of supervision (Rabinowitz, 1987:88). However, from this paper's examination of the interplay between the historical development and current practices, it appears that the existing theoretical foundation and practices of social work supervision do not extensively meet the dynamics of the contemporary international and local social work domain. The future thus holds distinct challenges encompassing the significance and timeliness of supervision in South Africa. To this end, the quotation from of Cicero in the Preface to Kadushin and Harkness's (2002:xvii) study is appropriate: "No wind is favourable unless you know the port to which you are heading". The modern translation in a supervision context could be: if we do not know where we are going with supervisory practices, we will probably end up somewhere else. 


\section{REFERENCES}

AMERICAN BOARD OF EXAMINERS IN CLINICAL SOCIAL WORK (ABECSW). 2004. Clinical supervision: a practice specialty of clinical social work. A Position Statement of the ABECSW.

AUSTIN, M.J. 1981. Supervisory management in the human services. Englewood Cliffs, NJ: Prentice-Hall, Inc.

BARETTE, J. 1968a. A few thoughts on supervision as a learning experience 1. Social Work/Maatskaplike Werk, 4(2):85-90.

BARETTE, J. 1968b. A few thoughts on supervision as a learning experience 2. Social Work/Maatskaplike Werk, 4(3):131-135.

BARKER, R.L. 1995. Social work dictionary ( $3^{\text {rd }}$ ed). Washington, DC: NASW Press.

BERNARD, J.M. \& GOODYEAR, R.K. 1992. Fundamentals of clinical supervision. Boston: Allyn \& Bacon.

BLUCKERT, B. 2008. Coaching supervision. [Online] Available: http://www.pbcoaching. com/articles/article-coaching-supervision.pdf [Accessed: 19/09/2009.]

BOGO, M. \& McKNIGHT, K. 2005. Clinical supervision in social work: a review of the research literature. The Clinical Supervisor, 24(1/2):49-67.

BOPAPE, M. 1968. Student supervision in casework training with special reference to Bantu Colleges in South Africa. Pretoria: University of South Africa. (Unpublished MA Thesis)

BOTHA, N.J. 1971. Supervisie in maatskaplike werk met besondere klem op drie partikuliere welsynsorganisasies. Stellenbosch: University of Stellenbosch. (Unpublished MA Thesis)

BOTHA, N.J. 1972. Supervisie in maatskaplike werk met besondere klem op drie partikuliere welsynsorganisasies. Social Work/Maatskaplike Werk, 8(2):72-82.

BOTHA, N.J 1985a. Die inhoud en vaardighede vir doeltreffende supervisie. Paper delivered at a symposium on supervision on 22-23 August, University of Pretoria.

BOTHA, N.J. 1985b. Onderrigmodel vir doeltreffende supervisie. Maatskaplike Werk/Social Work, 21(4):239-248.

BOTHA, N.J. 2002. Supervision and consultation in social work. Bloemfontein: Drufoma.

BOOLEY, M.S. 1996. The development of participatory management in supervision: An evaluative study. Stellenbosch: University of Stellenbosch. (Unpublished DPhil Dissertation)

BRACKETT, J.R. 1904. Supervision and education in charity. New York: MacMillan.

BRADLEY, G., ENGELBRECHT, L.K. \& HÖJER, S. 2010. Supervision: a force for change? Three stories told. International Social Work OnlineFirst, 24 June: 1-18. [Online] Available: http://isw.sagepub.com/cgi/rapidpdf/0020872809358401v1 [Accessed: 24/06/2010.]

BUNKER, D.R. \& WIJNBERG, M.H. 1988. Supervision and performance: Managing professionals in human service organizations. San Francisco: Jossey-Bass Publishers. 
BURNS, M.E. 1958. The historical development of the process of casework supervision as seen in literature of social work. Chicago: School of Social Service Administration, University of Chicago. (Unpublished PhD Dissertation)

COHEN, B. 1999. Intervention and supervision in strengths-based social work practice. Families in Society, 80(5):460-466.

COLEMAN, M. 2003. Supervision and the clinical social worker. Clinical Social Work. Practice Update, 3(2):1-4.

COLLINS-CAMARGO, C. \& KELLY, M.J. 2006. Supervisor as informal mentor: promoting professional development in public child welfare. The Clinical Supervisor, 25(1/2):127-146.

CONNOR, M. \& POKORA, J. 2007. Coaching \& mentoring at work. Developing effective practice. Berkshire: Open University Press.

DAWSON, J.B. 1926. The casework supervisor in a family agency. Family, 6:293-295.

DE BRUYN, M. 1985. Opleiding en toerusting van supervisors. Paper presented at a symposium on supervision. Pretoria: University of Pretoria, 22-23 August.

DE JAGER, J. 1962. Die indiensopleiding in die Departement van Volkswelsyn en Pensioene as vorm van praktykleiding. Mens en Gemeenskap, 111(2/4):167-175.

DEPARTMENT OF SOCIAL DEVELOPMENT, 2003. Strategic Plan of the Department of Social Development: 2003/4-2005/6. Pretoria.

DEPARTMENT OF SOCIAL DEVELOPMENT, 2005. Policy on the financial awards to service providers. Pretoria.

DEPARTMENT OF SOCIAL DEVELOPMENT. 2006. Draft recruitment and retention strategy for social workers. Pretoria: Department of Social Development.

DOEL, M. \& SHARDLOW, S. 1996. Social work in a changing world: perspective on practice learning. Aldershot: Gower House.

DU PLESSIS, G.A. 1965. Supervisie as hulpmiddel in maatskaplike werk met besondere aandag aan die Department van Volkswelsyn en Pensioene. Pretoria: University of Pretoria. (Unpublished MA Thesis)

DERCKSEN, J.W. 1973. Die onderhoud as hulpmiddel by supervisie van gevallewerk as metode in die maatskaplike werk. Pretoria: University of Pretoria. (Unpublished MA Thesis)

DEWANE, C.D. 2007. Supervisor, beware: ethical dangers in supervision. Social Work Today, 7(4):34-40.

EARL, N. 2008. Social work in social change. The profession and education of social workers in South Africa. Cape Town: HSRC Press.

ENGELBRECHT, L.K. 2002. 'n Maatskaplike ontwikkelingsgerigte perspektief op supervisie aan maatskaplikewerk-studente by opleidingsinstansies in Suid-Afrika. Stellenbosch: University of Stellenbosch. (Unpublished DPhil Dissertation)

ENGELBRECHT, L.K. 2004. Operationalising a competence model of supervision to empower social workers and students in South Africa. Social Work/Maatskaplike Werk, 40(2):206216. 
ENGELBRECHT, L.K. 2006a. Plumbing the brain drain of South African social workers migrating to the UK: Challenges for social service providers. Social Work/Maatskaplike Werk, 42(2):101-121.

ENGELBRECHT, L.K. 2006b. Cultural friendliness as a foundation for the support function in the supervision of social work students in South Africa. International Social Work, 49(2):256-266.

ERERA, I.P. \& LAZAR, A. 1994. The administrative and educational functions in supervision: Indications of incompatibility. The Clinical Supervisor, 12(2):39-56.

FERGUSON, I. 2009. No justice, no peace!: Reflections on social work, social conflict and reconstruction. Key note speech delivered at the first ENSACT Joint European Conference: Dubrovnik.

FIFTH INTERNATIONAL INTERDISCIPLINARY CONFERENCE ON CLINICAL SUPERVISION. 2009. The Clinical Supervisor, 28(1):109-111.

FOUCHÉ, C.B. 2005. Qualitative research designs. In: DE VOS, A.S. (ed) Research at grass roots. a primer for the caring professions. Pretoria: Van Schaik Publishers: 267-273.

GIBELMAN, M. 1995. What social workers do. Washington, DC: NASW Press.

GILBERT, C. 2009. Editorial. The Clinical Supervisor, 28(1-2):1-2.

GOCHROS, H. 2005. Interviewing. In: GRINNELL, R.M. \& UNRAU, Y.A. (eds) Social work research and evaluation. Quantitative and qualitative approaches $\left(7^{\text {th }} \mathrm{ed}\right)$. Oxford: Oxford University Press: 246-269.

GRINNELL, R.M., UNRAU, Y.A. \& WILLIAMS, M. 2005. Scientific inquiry and social work. In: GRINNELL, R.M \& UNRAU, Y.A. (eds) Social work research and evaluation. Quantitative and qualitative approaches ( $7^{\text {th }}$ ed.). Oxford: Oxford University Press: 4-21.

HARDCASTLE, D.A. 1991. Toward a model for supervision: a peer supervision pilot project. The Clinical Supervisor, 9(2):63-76.

HATTING, J.F.J. 1968. Die behoefte aan praktykleiding. Paper delivered at a field guidance conference. Wellington: Huguenot College, 30 September.

HAWKINS, P. \& SHOHET, R. 2006. Supervision in the helping professions ( $3^{\text {rd }}$ ed). Berkshire: Open University Press.

HENSLEY, P.H. 2002. The value of supervision. The Clinical Supervisor, 21(1):97-106.

HERSEY, P., BLANCHARD, K, \& JOHNSON, D. 1996. Managing of organizational behavior: utilizing human resources $\left(7^{\text {th }} \mathrm{ed}\right)$. Upper Saddle River, NJ: Prentice-Hall.

HOFFMANN, W. 1976. Performance of undergraduate students in field instruction in social work education. Johannesburg: University of the Witwatersrand. (Unpublished DPhil Thesis)

HOFFMANN, W. 1987. Social work supervision. In: McKENDRICK, B.W. (ed) Introduction to social work in South Africa. Pinetown: Owen Burgess Publishers: 206-248.

JUBY, C. \& SCANNAPIECO, M. 2007. Characteristics of workload management in public child welfare agencies. Administration in Social Work, 31(3):95-109.

KADUSHIN, A. 1976. Supervision in social work. New York: Columbia University Press. 
KADUSHIN, A. 1992. Supervision in social work $\left(3^{\text {rd }}\right.$ ed $)$. New York: Columbia University Press.

KADUSHIN, A. \& HARKNESS, D. 2002. Supervision in social work $\left(4^{\text {th }}\right.$ ed). New York: Columbia University Press.

KAUFMAN, K. \& SCHWARTZ, T. 2003. Models of supervision: shaping professional identity. The Clinical Supervisor, 22(1):143-158.

LAVE, J. \& WENGER, E. 1991. Situated learning. Legitimate peripheral participation. Cambridge: Cambridge University Press.

LEEDY, P.D. \& ORMROD, J.E. 2001. Practical research: planning and design ( $7^{\text {th }}$ ed). New Jersey: Merrill Prentice-Hall.

LEWIS, J.A., PACKARD, T. \& LEWIS, M.D. 2007. Management of human service programs $\left(4^{\text {th }}\right.$ ed $)$. Belmont: Thomson Brooks/Cole.

LOMBARD, A., GROBBELAAR, M. \& PRUIS, S. 2003. Standards for social work qualifications in South Africa. Social Work/Maatskaplike Werk, 39(1):1-17.

MARSHALL, C. \& ROSSMAN, G.B. 1999. Designing qualitative research $\left(3^{\text {rd }} \mathrm{ed}\right)$. London: Sage Publications.

McMURTY, S.L. 2005. Surveys. In: GRINNELL, R.M. \& UNRAU, Y.A. (eds) Social work research and evaluation. Quantitative and qualitative approaches $\left(7^{\text {th }} \mathrm{ed}\right)$. Oxford: Oxford University Press: 272-287.

MIDDLEMAN, R.R. \& RHODES, G.B. 1985. Competent supervision. Making imaginative judgements. Englewood Cliffs: NJ: Prentice-Hall.

MÜLLER, A. 1965. Opleiding vir maatskaplike werkers met spesiale verwysing na SuidAfrika. Stellenbosch: University of Stellenbosch. (Unpublished DPhil Dissertation)

MUNSON, C. E. 1993. Clinical social work supervision $\left(2^{\text {nd }}\right.$ ed). New York: Haworth Press.

MUNSON, C.E. 2002. Handbook of clinical social work supervision. New York: The Haworth Press.

NYE, C. 2007. Dependence and independence in clinical supervision: an application of Vygotsky's developmental learning theory. The Clinical Supervisor, 26(1/2):81-98.

O'DONOGHUE, K. 2002. Global-vision, local-vision, personal-vision and social work supervision. Paper presented to Aotearoa New Zealand Association of Social Workers Conference, Christchurch, 31October-2 November.

PAGE, A.C. \& STRITZKE, W.G.K. 2006. Clinical psychology for trainees: foundations of science-informed practice. London: Cambridge University Press.

PELSER, M.F. 1985. Die wetenskaplik professionele regverdiging van supervisie vir maatskaplike werk. Paper delivered at a supervision symposium, Pretoria: University of Pretoria, 22-23 August.

PELSER, M.F. 1988. Supervisie in maatskaplike werk. Riglyne vir die praktyk. Pretoria: University of Pretoria. (Unpublished DPhil Thesis)

PERLMAN, H.H. 1967. Social casework. A Problem-solving process. Chicago: University Press. 
PERRAULT, E.L.J. \& COLEMAN, H.D.J. 2005. Coaching within social work field education. The Clinical Supervisor, 23(2):47-64.

PETTES, D.E. 1967. Supervision in Social Work. A method of student training and staff development. London: George Allen \& Unwin.

PIETERSE, J. E. 1961. Praktykleiding in groepwerk. Mens en Gemeenskap, 11(3/4):155-162.

RABINOWITZ, J. 1987. Why ongoing supervision in social casework: an historical analysis. The Clinical Supervisor, 5(3):79-90.

RICHMOND, M. E. 1899. Friendly visiting among the poor: a handbook for charity workers. New York: MacMillan.

ROBINSON, V. 1936. Supervision in social work. Chapel Hill: The University of North Carolina Press.

RSA (REPUBLIC OF SOUTH AFRICA). 1978. Act on Social and Associated Workers, Act 110 of 1978. Pretoria: Government Printers.

RSA (REPUBLIC OF SOUTH AFRICA). 1997. Ministry of Welfare and Population Development. White Paper for Social Welfare. Notice 1108 of 1997, Government Gazette, vol. 386, No. 18166 of 8 August. Pretoria, Government Printers.

RSA (REPUBLIC OF SOUTH AFRICA). 2006a. Childrens's Act, No.38 of 2005. Government Gazette, vol. 492, 19 June. No 28944: Cape Town.

RSA (REPUBLIC OF SOUTH AFRICA). 2006b. Department of Social Development. Integrated service delivery model towards improved social services. Pretoria, Government Printers.

SACSSP (SOUTH AFRICAN COUNCIL FOR SOCIAL SERVICE PROFESSIONS). 2007. Policy guidelines for course of conduct, code of ethics and the rules for social workers. [Online] Available: http://www.sacssp.co.za/UserFiles/File/SACSSP\%20Code\%20Ethics.pdf [Accessed: 02/06/2009].

SACSSP (SOUTH AFRICAN COUNCIL FOR SOCIAL SERVICE PROFESSIONS). 2008. Draft executive summary of the research report on the demarcation of social services: professionalization and specialization. [Online] Available: http://www.sacssp. co.za/User Files/File/RESEARCH\%20EXECUTIVE\%20SUMMARY\%20edited\%20\%20amendedff.doc.

[Accessed: 02/06/2009].

SCHUTT, R.K. 2005. Sampling. In: GRINNELL, R.M \& UNRAU, Y.A. (eds) Social work research and evaluation. Quantitative and qualitative approaches $\left(7^{\text {th }} \mathrm{ed}\right)$. Oxford: Oxford University Press: 150-169.

SHULMAN, L. 1993. Interactional supervision. Washington, DC: NASW Press.

SHULMAN, L. 1995. Supervision and consultation. Encyclopedia of Social Work (19 ${ }^{\text {th }}$ ed). Silver Spring, MD: National Association of Social Workers: 2373-2379.

SIEPERT, J.D., McMURTY, S.L. \& McCLELLAND, R.W. 2005. In: GRINNELL, R.M \& UNRAU, Y.A. (eds) Social work research and evaluation. Quantitative and qualitative approaches $\left(7^{\text {th }}\right.$ ed). Oxford: Oxford University Press: 316-328.

SMIT, S.J. 1972. Supervisie binne groepsverband. Social Work/Maatskaplike Werk, 8(1):2226. 
STAKE, R. 1995. The art of case study research. Thousand Oaks: Sage Publications.

TERMINOLOGY COMMITTEE FOR SOCIAL WORK. 1995. New dictionary of social work. Cape Town: CTP Book Printers.

TROMSKI-KLINGSHIRN, D. 2006. Should the clinical supervisor be the administrative supervisor? The ethics versus the reality. The Clinical Supervisor, 25(1/2):53-63.

TSUI, M. \& HO, W. 1997. In search of a comprehensive model of social work supervision. The Clinical Supervisor, 16(2):181-202.

TSUI, M. 1997. The roots of social work supervision: An historical review. The Clinical Supervisor, 15(2):191-198.

TSUI, M. 2005. Social work supervision. Contexts and concepts. London: Sage Publications. VAKTAALKOMITEE VIR MAATSKAPLIKE WERK. 1971. Verklarende Afrikaanse Woordeboek vir Maatskaplike Werk. Departement Volkswelsyn en Pensioene. Pretoria: Government Printer.

Dr Lambert Engelbrecht, Department of Social Work, University of Stellenbosch, Stellenbosch, South Africa. 